\title{
State, Democracy, Socialism
}

The 'third way' to socialism was complementary to the Austromarxists' reflections on the state and the direction that Social-Democratic politics aspired to take within the bourgeois-democratic framework. The idiosyncratic quality of these analyses was that they understood the state, law, and forms of political order (democracy, dictatorship) as mutually independent forms: they distinguished between a formal and a sociological order - i.e. they abstracted the form of phenomena from their content and social function. The views of Hans Kelsen, a moderate liberal theorist on law and the state and founder of the 'pure theory of law', provided the basis for this differentiation. ${ }^{1}$ Three fundamental theses of legal normativism were most influential in the Austromarxists' theory of state formation. The first was of a purely formal character of political and legal categories, which granted them the status of a priori ideas. The second served to justify the dualism between being and ought, form and content, facts and values, causality and normativity, and, ultimately, law and politics. The third was the assumption that the state was synonymous with the law, and as such the territorial order was identical to the coercive order. Owing to the fact that they drew on Kelsen's 'pure theory of law', the Austromarxists developed perspectives on democracy and the state which are still discussed today. ${ }^{2}$

The Austromarxian theory of law and the state was devised mainly by Karl Renner and Max Adler. Renner in particular focused on the formal aspects of the categories under investigation, while Adler researched both normative and sociological functions. Despite the considerable differences between their positions, Renner and Adler agreed, along with Bauer, that the working class could

1 The 'pure theory of law' was devised under the influence of neo-Kantianism and legal positivism. Kelsen adopted two methodological guiding principles from neo-Kantianism: formalism and the dualism of being and ought. He amalgamated ahistoricism, criticism and relativism with legal positivism. Furthermore, Kelsen's normativity of law drew on positivism's notion that the origins of law were not scientific, since the essence of law consists of a formal order of norms. According to the 'pure theory of law', norms are acts of will, and the basis of the legal system, the Grundnorm (fundamental norm), is a logical precondition for legal recognition in the Kantian sense. The specific character of legal science lay in the fact that legal norms are investigated only on the basis of legislation, while social conditions are not taken into account.

2 See, for example, Sartori 1987.

(C) EWA CZERWIŃSKA-SCHUPP, 2017 | DOI: 10.1163/9789004325838_007 
take control of the institutions of the capitalist state by democratic means and give them new class content. Their belief that it was not necessary to eradicate the old state apparatus, as it could automatically be made to serve proletarian rule, was one of the factors that determined the Austrian Social Democrats' favourable attitude toward parliamentarism. This perspective stood in stark contradiction to Lenin, who argued that the permanence of revolutionary processes depended on the abolition of the bourgeois state.

Unlike Max Adler and Renner, Bauer paid little attention to theories of law and the state prior to World War I. Instead, he concentrated on sociological analyses of the social content and function of the state, arriving at resolutions consistent with Marxist theory: the state had to be understood as a ruling instrument of the economically dominant classes. Consequently, the bourgeois state was radically counterposed to the proletarian state. This conception corresponded with Bauer's historic-philosophical proclivity, according to which the working class and the bourgeoisie were the primary antagonistic agents in the historical process.

In reference to the perception of the state as a class state, Bauer stressed the superiority of the socialist over the capitalist state in all dimensions of social life, including in the economic, political and moral domains. One cannot avoid the impression, however, that many of his statements on the state and society of the future were not strictly theoretical, but propagandistic - as was also the case with his temporary criticisms of the bourgeois state.

Bauer's statements on state socialism drew on a variety of assertions common in Marxist literature, but which played no part in the political practice of Social Democracy. They were essentially prognoses about the emergence of a classless society in which a democratically appointed government would replace the coercive state apparatus and self-manage production, exchange and administration. What specific forms government would take in the proletarian state after a successful socialist revolution was a question that was approached very cautiously. Had it been raised programmatically, for instance as a demand for proletarian dictatorship, the party might have no longer found it possible to win the middle classes as voters, and thus the Social Democrats' preferred strategy and tactics would then fail. Secondly, Bauer thought that the concentration and centralisation of capital represented an early stage of the socialist planned economy. Tied into this was the idea that the social process had an evolutionary disposition, and that the legal and political institutions of the bourgeois state would 'grow into' institutions of the socialist state. This idea provided some of the basis for the SDAP's focus on short-term tactics rather than distant, strategic objectives. Thirdly, Bauer decidedly distinguished between two dimensions of the state: the state as a formal organisation of soci- 
ety, and the state as a specific legal and political order. Like Max Adler, he saw the bourgeois-democratic state as a tool of bourgeois rule, stressing that its legal system only served to fortify economic and class subjugation. Like other Austromarxists, however, he prioritised the formal rather than the class facet. Hence, as a mature politician, he ratified a notion borrowed from Lassalle, a view also present in the beliefs of Renner and Kelsen - under capitalist property relations, he argued, the state had a neutral character and was beneficial to the working class. ${ }^{3}$ Despite his criticisms, Bauer's theory of the state as 'balance of class power' testified to his respect for the bourgeois state and democracy as formal institutions. Democracy was not only the overriding category in his state theory; it was also the cardinal value in his perception of democratic socialism.

This theory can be found in Bauer's works from 1923-4, Die österreichische Revolution (The Austrian Revolution) and Das Gleichgewicht der Klassenkräfte (The Balance of Class Power). The fact that he revisited the theory in his 19346 texts, Demokratie und Sozialismus (Democracy and Socialism) and Zwischen zwei Weltkriegen (Between Two World Wars) demonstrates how significant he considered it to be. The aims it intended to serve culminated from sociohistorical conditions: initially, 'balance' theory provided the antecedent for the practice of democratically transforming capitalism into socialism. Later, he used it to explain the mechanisms by which fascism could obtain power. ${ }^{4}$ Its constitutional thesis was that the capitalist state would enter a period during which the balance of antagonistic classes was practically equal. ${ }^{5}$ Bauer based

3 In the 1920s, Renner stated that in the contemporary bourgeois state, there is a growing tendency for 'the economy ... to exclusively serve the capitalist class, and for the state to predominately serve the proletariat' (our translation). Original: 'die Ökonomie ... immer ausschließlicher der Kapitalistenklasse, der Staat immer vorwiegender dem Proletariat dient'. This was based on Kelsen's thesis from Kelsen 1923, p. 105.

4 For interesting commentary on both aspects of Bauer's theory of the 'balance of class power', see Saage 1986, pp. 83-5 and Saage 1990, pp. 67-76.

5 The concept did not refer to arithmetic equality between the bourgeoisie and the proletariat, but rather to the political strength of both. This is echoed in Kautsky's Die proletarische Revolution und ihr Programm (The Proletarian Revolution and its Programme, 1922), where he finds that a state of balance between the bourgeoisie and the proletariat can be achieved. With universal suffrage at its disposal and because of its increased electoral potential, the working class can defend itself against being pushed onto the defensive. Kautsky concluded 
this on Marx's periodisation of the 1848 revolution in France and his own analysis of the socio-political dynamics in Austria after World War I. ${ }^{6}$

When analysing the revolutionary period in Austria, Bauer distinguished between three stages: the dominance of the working class after 1918, the balance of class power from 1919-22, and the restoration of bourgeois power after 1922. He argued that between the years of 1919 and 1922, neither the bourgeoisie nor the proletariat were strong enough to rule on their own. Unlike in France or Italy, the state apparatus did not become independent of class forces, but rather state power was shared between the classes. As Bauer argued, disjuncture occurred as state organs had been replaced by the organisations of the working class. This development allowed for an extraordinary type of state to emerge, which Bauer christened 'balance of class power' or, alternatively, a people's republic. Characterising this type of state, he wrote with reference to the First Republic, which existed until 1922:

Thus the Republic was neither a bourgeois nor a proletarian republic. In this phase, the Republic was not a class State, that is, not an instrument for the domination of one class over other classes, but the outcome of a compromise between the classes, a result of the balance of class power. Just as the Republic arose in October, 1918, upon the basis of a social contract, a political treaty between the three great parties which represented the three classes of society, so it was only able to survive by means of daily compromises between the classes. ${ }^{7}$

The affinity between his findings and the traditional concept of the state advocated by the right wing of the party was remarkable. The latter were influenced by Bernstein, according to whom the modern bourgeois state was an instrument to obtain the common interests of society and, consequently, represented a transitional stage between capitalism and socialism.

that upsetting the balance of class power would lead to a civil war and destroy the domestic economy.

6 It was not without genuine bases, the first of which was the existing economic, geographical, and demographic situation in the country - i.e. tensions between industrial Vienna and the dispersed agrarian and relatively sparsely populated provinces. The second was the socio-political situation of Austria during the revolutionary period: the workers had gained considerable control over the army and police, which put certain limits on the bourgeoisie. See also Saage 1986, p. 86.

7 Bauer 1925, p. 246. This depiction was inaccurate. Bauer conveniently overlooked the fact that, in 1920, the bourgeois parties had assumed state power on their own. 
Bauer also strove to consider the premises on which the hypothesis of a gradually changing bourgeois state depended. He was convinced that the balance of class power had allowed for the emergence of an 'ultra-democratic' form of state, a people's republic. Its essence was supposedly a variation of the parliamentary system modified and adjusted by a functional democracy. The political order proposed by Bauer was defined by the subordination of the executive to parliamentary control, additionally reinforced by social organisations. Bauer assumed that the government would not be able to rely solely on an elected parliament due to strong, extra-parliamentary and primarily working-class pressure groups. It would have to seek approval from autonomous citizens' organisations to legitimise its conduct. For Bauer, the shifting paradigms of exerting power implied that the function of the state was changing too. It would transition from acting as watchman of the capitalist economic and social order to mediator between the sectional interests of different social groups. According to 'balance of class power' state theory, maintaining that equilibrium was a condition for the development of reformist socialism. In reality, concessions granted to the working class by the bourgeoisie were measures to stabilise capitalism, even if they served the temporary interests of the working masses. The belief that the bourgeoisie and the proletariat could permanently and amicably share political power in any state proved to be an illusion. Even Bauer was conscious that underneath the temporary balance of class power, there was a tendency for class antagonisms to thrive. In his polemic with Kelsen, he acknowledged that the 'balance of class power' was a transitional phase in the development of the state, and that it could evolve in two opposite directions. It would either lead to the working class confiscating state power or result in a situation where bourgeois dominance was restored and the proletariat driven to the peripheries. ${ }^{8}$ As chair of the workers' party, he wanted to sustain the masses' faith in reformist practice. Hence, he optimistically declared that a state based on the 'balance of class power' could be remodelled into a proletarian state. This was based on the notion - de facto underappreciated in Marxism - that legal institutions could regulate the economy. Bauer accorded great significance to the project of changing consciousness. He wanted the working class to achieve hegemony in the immaterial world. For him, these projects were the means by which to transform the bourgeois state democratically. Concerning the basic conditions in West European democracies as opposed to, say, Soviet Russia, he was inclined to believe that the political and legal superstructure was relatively independent of the economic structure. To conceive

8 Compare also Saage 1986, p. 146. 
of the relation between politics and the economy in this way is now customary, yet it was novel in Marxist thinking at the time. However, Bauer's idea of a far-reaching autonomy of politics led him to overestimate the role of superstructural political forms at the expense of economic relations. ${ }^{9}$ Consequently, his overall assessment of the people's republic was misguided.

Bauer's references about the emergence of the First Republic imply that during the revolutionary period, it was a class-neutral state. The two most important social classes allegedly possessed similar strength in the power struggle. It is difficult to see the veracity of this. After all, the 'balance of classes' in the First Republic was based on capitalist property relations. Maintaining these property relations was synonymous with preserving the rule of the economically dominant classes, even if their political strength was temporarily weakened. The participation of delegates of the workers' party in government did not visibly change the socio-economic structure. Without wanting to depreciate the merit of Bauer's analyses, nonetheless what he glorified as a people's republic was in actuality a class state of the bourgeoisie. For all its rational and positive assets, workers' participation in production and superstructural institutions in this state was limited.

Similarly, another idea in Bauer's analysis also falls short. Namely, his analogy between the political emancipation of the bourgeoisie in the feudal state and the political emancipation of the proletariat in the people's republic. According to Bauer, a provisional balance between the class of feudal landowners and the bourgeoisie gradually allowed the latter to conquer the state apparatus. Moreover, Bauer saw an analogy between the mechanisms by which the bourgeoisie took power and the position of the working class in the bourgeois state. That is to say, it would gradually amass control over all institutions until it ruled on its own. Legally guaranteed forms of co-operation between the bourgeoisie and proletariat would secure the full emancipation of the proletariat. For many, the mechanical analogy between the bourgeois rise to power and the working-class struggle for the same ends was unfounded then, and remains so today. In feudal society, the bourgeoisie first solidified its economic position and then used it to gradually ascend to power. A comparable path is unavailable for the working class in capitalist states. Social reforms, trade unions, cooperatives and industrial councils achieved meaningful social change in the political and economic capitalist order, yet they have still not shaken the foundations of capitalist relations of production to any degree.

9 Kelsen voiced the same objection to Bauer's theory. See Kelsen 1965, p. 273. Further criticism of Bauer's theory can be found in Kelsen 1924, pp. 50-6. 
As a politician well acquainted with the socio-political dynamics within the state, Bauer knew that the bourgeoisie would fight to rule exclusively as soon as it had buttressed its political standing. He also realised that it would attempt to push the working class out of all political, administrative and economic bodies that limited bourgeois economic power. Prophetically, he predicted in the 1920 s that the bourgeoisie would abandon democratic positions the moment democracy was no longer able to safeguard its economic interests. Bauer came to experience this first-hand after 1922, when the bloc of bourgeois parties, emboldened by the fact that Seipel's plans for the Geneva Protocol had been successful, repealed some of the concessions achieved by the working class during the revolutionary period. In practice, abstracted from socio-economic realities, the 'social balance' theory of the state assumed the concrete forms of the bourgeois democratic republic in the 1920 and the authoritarian regime after 1934 .

Bauer's 'balance of class power' theory provoked ire from Lenin ${ }^{10}$ - understandably so, from a Communist perspective - and was dismissed as a pettybourgeois delusion on the part of the Social Democrats. ${ }^{11}$ Nor was it spared criticism from bourgeois theorists. Kelsen accused Bauer of revising the Marxist theory of class struggle and abandoning Marxist positions, claiming that he had forsaken revolutionary perspectives. ${ }^{12}$ This charge would have been justified had Bauer ever endorsed Marx's theory of armed revolution. In truth, his concept of the state as 'balance of class power' was an integral part of his overall vision of a democratic road to socialism. Bauer's theory of the state allowed him to provide a common ground of cross-class understanding and co-operation. Its sincere actual purpose was to vindicate the SDAP's strategies and legitimise the coalition policies in which it had engaged since the beginning of the First Republic. The idea that it was necessary for the workers' party to forge coalitions and co-operate with bourgeois parties was the result of a specific assessment of bourgeois democracy and a corresponding strategic approach. ${ }^{13}$

10 Lenin unabashedly attacked it as being harmful for the working class - see Lenin 1965 , pp. $460-80$.

11 See Adler 1981, pp. 198-203.

12 See Kelsen 1924.

13 Kautsky shared this perspective - see Kautsky 1922, p. 106. 
The rapid transformation of Austria from a monarchy into a republic shaped public opinion on democracy and predetermined its fate. As Pelinka notes, the new republic lacked a parliamentary tradition. In its early days, the citizens of the new republic felt no loyalty towards the state, and consequently, society did not respect the principles of the political order. ${ }^{14}$ Nor did the existing bourgeois parties have any aspirations to reinforce democratic political structures; after all, the proclamation of the republic had not been the culmination of their political struggles, but was forced upon them by the postwar situation in Austria. The masses entrusted their loyalty to their respective political affiliations before pledging any allegiance to the democratic republic. Since there was no universal interpretation of democracy, an established way for the party to function within the system of political democracy was equally non-existent. ${ }^{15}$ Thus, Austrian parliament became a site of struggle between competing political elites. ${ }^{16}$ In contrast to other political groups, the Austrian Social Democrats occupied a distinct place: from the earliest days of the republic, they defended bourgeois democracy.

Attitudes towards democracy varied within the SDAP, and this state of affairs persisted until the party congress of Linz. The fact that various definitions of the contentious concept coexisted within the party further sharpened the existing polarisation. Depending on who one talked to, democracy could mean, for instance, a system for the common good, the rule of a homogeneous people, a way to peacefully reconcile opposing interests, or the rule of the majority. ${ }^{17}$ Party comrades agreed only on foregrounding universal humanist aims and democratic values manifest in the protection of civil rights and human dignity, and on democracy's vital role in the decentralisation of state power and the political education of the masses. The wide range of interpretations inspired the party's main ideologists to discern the theoretical foundations of democracy. As a result of their efforts, however, three different theories of democracy existed within Austromarxist political theory: Bauer's, Renner's and Max Adler's. ${ }^{18}$ In contrast to the other two, Bauer's theory centred on the axiological

\footnotetext{
14 See Pelinka 1982, p. 82.

15 On the shortcomings of democracy in Austria, compare Reimann's insightful disquisition in Reimann 1968, p. 154.

16 See Pelinka 1982, p. 84.

17 Compare Pfabigan 1982, p. 221.

18 I wrote on their similarities and differences in Nurt medjacji - see Czerwińska 1991, pp. $283-97$.
} 
dimension of democracy and its role in establishing the bürgerliche Gesellschaft (civil society). Bauer unified both aspects - the evaluative and the political in his model, which he based on political and functional democracy.

Indeed, it is evident from Bauer's writings that political democracy played a fundamental role in his theory. Drawing on Kelsen's arguments, his analysis distinguished between democracy's formal and social content. In all statements on democracy as a principle that shaped the political order, Bauer consistently pointed out its ahistorical, class-neutral qualities. With reference to JeanJacques Rousseau, he proclaimed that popular sovereignty was the core principle of this form of state organisation - i.e. the free will of the people to decide whom to entrust with governing the state. Here, 'the people' were understood as a political rather than class order. Again with reference to Kelsen, Bauer designed a distinct model of representative democracy, which became one of several competing theories of democracy.

According to Bauer, the essential component of democracy was the formal majority principle, with universal suffrage as the benchmark that decided whether the majority really had a say. Bauer argued that the proletariat was not yet politically mature enough to acquire power because it did not enjoy the support of the majority of society. Secondly, he concluded from this that the state performed its duties on behalf of the whole of society. Bauer was convinced that the majority had to strive for the common good instead of enforcing sectional objectives if it wanted to remain in power. For him, equal opportunities to obtain power and the right to change one's political views were intrinsic to the majority principle, and to consent to this principle was crucial for a healthy democracy. These traits allowed democracy to survive crises in the most effective manner: opposing interests were brought to the surface and reconciled through legally defined regulatory mechanisms. Therefore, preserving social peace by means of political compromise was a hallmark of democracy, which Kelsen also conceded. No doubt, a liberal thinker such as Thomas Vernor Smith, according to whom the term political democracy denoted a process of resolving collective conflicts through legislative bodies, would fully subscribe to this interpretation. ${ }^{19}$

For Bauer, freedom was the second fundamental principle of the democratic political order, the right of the people to elect their own government, and both to entrust it with authority and to deprive it of authority. ${ }^{20}$ An important aspect of his theory was that he connoted freedom with democracy and socialism.

19 See Smith 1942, p. 2.

$20 \quad$ See Bauer 1976p, p. 194. 
Unlike Max Adler, however, he was far removed from associating the achievement of freedom in the collective sense with the socialist order. Rather, he advocated ethical individualism: democracy's aim was to secure for individuals a right to privacy and protect inalienable rights, interests, and opinions. The state, even one founded on the principle of popular sovereignty, should not encroach upon these. Nonetheless, freedom under democratic conditions was not to be understood as individualist anarchism, but as a principle that facilitated unified, collective action within the framework of the adopted legal order. Freedom understood in this way, Bauer argued, secured legal protection for minorities and granted them free expression. It therefore offered minorities ample opportunity to become the majority and allowed for power to be reassigned. Bauer based his assumption that the Social Democrats would eventually gain command of the levers of power on this premise. In his early texts, he typically neglected the principles of social and economic equality as basic prerequisites for democracy. This not only betrayed the influence of Kelsen's thought, but also testified to the classical Austromarxist proclivity for favouring the political over social emancipation.

One may wonder whether Bauer was not wary that certain excesses of the democratic state order, toward which both Kelsen and Max Weber were vigilant, might pose a threat to political democracy itself. That is, its tendency towards bureaucratisation (political representatives losing touch with the electorate), party leaders striving to increase their influence in the executive sphere, and ultimately, the propensity of delegates to put their own party interests above the interests of voters. In reality, Bauer had no such reservations, since he overestimated the potential of the democratic political order. The first reason was that in the early stages of modern democracy, these threats were not as pronounced as they are now. The second was that Bauer, like Karl Popper many years later, thought that political democracy allowed the governed to fully regulate the government and thus prevent abuses of power. ${ }^{21}$

There was also a sociological logic to Bauer's approach to democracy, albeit a latent one. In his view, prioritising formal categories - for example, the majority and freedom principles as formally understood - above class did not imply that the largest concern for the social content of power was brushed aside. Marx's theory one-sidedly equated political democracy with bourgeois democracy, which it regarded as an apparatus of class rule and oppression. According to Marxian doctrine, the economy thwarted the autonomy of politics. In light of Western democracies, Bauer far from reduced himself to such simplistic 
limitations on the dependency between economic conditions and the political system, even if by doing so he contradicted some of his own statements on the function of objective historical factors. He was inclined to agree with Marx on one point: democracy remained an instrument of class rule, and because it preserved the rule of capital, the bourgeois democratic republic was a class state of the bourgeoisie. Yet essentially, Bauer upheld that legal forms and institutions were relatively independent from the economic base, believing it possible to regulate the economy through legal institutions. According to Bauer, the social content of power under democracy was determined by the existing composition of class forces. This composition, in turn, was determined by not only economic but also social factors, such as the strength of the class, degree of organisation, strength of its ideology, and political maturity. From this he made two observations, both of which illustrated the decisive necessity of political democracy in political practice. The first, in short, is as follows: political democracy facilitated the democratic control of economic power even in the capitalist state, it could already become an instrument to limit exploitation based on capital. The second reiterated a fundamental conviction of Austromarxist revolutionary theory. It determined that political democracy enabled the proletariat to emancipate itself economically because it offered the possibility of winning social hegemony 'by intellectual means'. It was therefore a sufficient condition for the seizure of power by the proletariat.

For Bauer, parliament was significant in political democracy, yet it would be simplistic to claim that he identified democracy with the system of parliamentary representation. Bauer explained the difference as follows: 'Democracy that is more than parliamentarism, more than the voice of legal institutions. For me, the state constitution offers the best possible guarantee for individual intellectual freedom' (our translation). ${ }^{22}$ This argument was informed by his aspiration to extend the democratic principle of popular sovereignty to all areas of social activity, especially the economic and political realms. Admittedly, Bauer equated parliamentarism and political democracy whenever he referred to it. His position was a faithful reiteration of Kelsen's ideas - for Kelsen, parliamentarism manifestly represented the only political form 'in which the idea of democracy can be fulfilled within today's social reality. Thus a decision about parliamentarism is at the same time a decision about democracy'. ${ }^{23}$ Bauer and

22 'Die Demokratie - das ist mehr als der Parlamentarismus, mehr als eine Stimme juristischer Institutionen. Sie ist mir die Staatsverfassung, die die bestmöglichen Bürgschaften der individuellen, der geistigen Freiheit gibt' - Bauer 1980j, p. 487. 
Kelsen both believed that true freedom could only be obtained through parliamentary democracy. Moreover, both theorists considered parliamentarism the only tool that could keep class antagonisms within certain limits.

Bauer was sceptical towards parliamentarism during the early period of his political activity. Certainly, the reason was that at the beginning of the twentieth century, the working class could not look back on many successes on the parliamentary stage. ${ }^{24}$ The slur 'parliamentary cretinism', which, already present in Marx's work and used by Bauer in 1910, heaped scorn on the notion that the capitalist class system could be transformed through parliament and was a popular phrase amongst workers. All the same, Bauer's critique of parliamentarism had an ideological character. He confined himself to stating that the balance of forces in parliament was a reflection of the social and class order, and that only a social revolution could change it. Notably, this verdict did not stop him from endorsing Victor Adler's choice of parliament as the main weapon of class struggle.

Bauer's critique of parliamentarism, which he voiced mainly in public appearances, intended to cultivate the working masses' belief in the revolutionary nature of the party. In fact, Bauer had always been convinced that parliament would decisively assist in granting the working class power. This belief was based on the idea that parliament was by nature class-neutral. Given the actual parliamentary dynamics, it is fair to say that this was misleading. The supremacy of the bourgeois over Social Democracy was a permanent condition, and the bourgeois government possessed not only the means of state repression, but also ideological influence, which Bauer himself acknowledged. His evaluation as to the degree that the proletariat could use parliament for the purpose of class struggle is worth further examination. Frankly, Bauer argued on more than one occasion that the proletariat was not politically mature enough. ${ }^{25}$ It is difficult to argue with this. At the time, the political consciousness of the working class was not sufficiently advanced for it to act as an independent political force. The Bolsheviks, confident in the veracity of their theory, were alone in their assumption that seizing power, building a new political order by decree, and proclaiming the party to be the leading force of the nation could accomplish a sufficient level of working-class political sophistication to efficiently

24 At the end of the nineteenth century, both wings of the Austrian workers' movement moderate and radical - were opposed to leading the political struggle in parliament. The situation changed following the unification of the workers' movement in Hainfeld, when Victor Adler declared that parliament was the crucial site of struggle for the working class to win social reforms and extend political liberties.

For example, in Bauer 1976n, p. 483. 
administer a state. As is well-known, these hopes were already squandered in the early stages of the Russian experiment. History has shown that the position of moderate Social Democrats, who had a realistic picture of the working class and viewed bourgeois democracy precisely as a tool of political education, was justified.

Likewise, Bauer's work was shaped by the belief in the progressive character of bourgeois democracy, even if this was a tense relationship. For many years, he stressed democracy's benefits for the political emancipation of society, yet at the same time pointed to its deficits, which were rooted in capitalist property relations. While claiming that bourgeois democracy was a prop that supported the economic and ideological power of the propertied classes, he did not go as far as to consider the capitalist-friendly status quo as a permanent condition. Economic and extra-economic means of repression, he argued, would only remain in the hands of capitalists as long as they were able to present their interest as the interest of all classes. They dominated the bourgeois political parties, and therefore the middle classes and part of the working class, only because they claimed that this interest had to be pursued for the sake of the economy. Bauer's polemics against Marx and particularly Lenin's arguments require some attention. For both thinkers, every government, be it democratic or not, was a dictatorship of the ruling class over the ruled classes. Consequently, bourgeois democracy was synonymous with a dictatorship of the bourgeoisie. In his defence of bourgeois democracy, Bauer admonished Adler's belief that the Austrian bourgeois governments were essentially dictatorial in the political sense of unrestricted power. According to Bauer, the minority rule of capital was secured by a majority rule of bourgeois parties that accepted the rule of capital - this, for him, was the specific character of bourgeois democracy. ${ }^{26}$ Although Bauer held bourgeois democracy in high esteem,

26 'The point is precisely that the rule of the capitalist class in democracy is not an unrestricted rule of the capitalist. One denies oneself the recognition of historical particularity if one ... regards every class rule as a class dictatorship ... [I]t is precisely the specific features of democracy that get lost in the process: that bourgeois democracy does not yet represent majority rule, but a minority rule of the big bourgeoisie through the majority rule of the bourgeois mass parties. On the other hand, the requirements of majority government place limits on the class rule of the big bourgeoisie, thus distinguishing democracy from the unlimited rule known as dictatorship' (our translation). Original: 'Die Herrschaft der Kapitalistenklasse in der Demokratie ist eben nicht eine unbeschränkte Diktatur der Kapitalistenklasse; man macht sich selbst die Erkenntnis der geschichtlichen Besonderheit der einzelnen Staatsformen unmöglich, wenn man ... jede Klassenherrschaft für eine Klassendiktatur ansieht ... Dabei geht gerade das Spezifische der Demokratie ver- 
he was aware of its intrinsic contradiction between economic power and political equality of all classes. Because it tied in with his vision of a future state, he dedicated most of his attention to this until the late 1920 .

Bauer admitted on more than one occasion that the victory of bourgeois democracy was also beneficial for the working class because it expedited its political, if not social, emancipation. Like Marx, he believed that democracy could only be fully realised in a classless society, where economic factors could no longer compromise the freedom and equality of all. Even in his earliest writings, Bauer spoke of the necessity for the proletariat to use democracy for its advantage and, by extension, for the liberation of humanity. Many theorists of Western Social Democracy, such as Kautsky and Renner, but also Mieczysław Niedziałkowski and other Polish Social Democrats, agreed that bourgeois democracy was the most favourable platform for the proletarian liberation struggle. They believed that parliament was a training ground for the working class to prepare for power, a propaganda platform for socialist ideas, a means of political education, and, above all, a tool for garnering support from beyond the remit of the working class. In Bauer's opinion, the latter two aspects were particularly important. According to his idea of revolution, winning the parliamentary majority would prelude the autonomous seizure of power by the working class and usher in an era of social revolution.

For most of his life, Bauer's political activity was defined by his conviction that parliamentary democracy would allow the proletariat to transform the capitalist system into a socialist order peacefully. This is certainly why Leser believes that, for Bauer, parliamentary democracy was nothing more than a transitional stage on the road to socialism. ${ }^{27}$ One should exercise some caution with this assessment, however. Bauer, who also wrote a pamphlet entitled 'Um die Demokratie' ('For the Sake of Democracy'), primarily recognised political democracy as an objective in its own right, yet at the same time valued its relevance for the Social-Democratic strategy. Bauer's confidence in the valu-

loren: dass die bürgerliche Demokratie eben noch nicht Mehrheitsherrschaft, sondern Minderheitsherrschaft der Großbourgeoisie mittels Mehrheitsregierung der bürgerlichen Massenparteien ist, und dass anderseits gerade die Notwendigkeiten der Mehrheitsregierung der Klassenherrschaft der Großbourgeoisie Schranken setzen und dadurch die Demokratie von der Diktatur, der schrankenlosen Herrschaft unterscheiden' - Bauer 1980r, p. 208.

27 See Leser 1968, p. 84. It is an undisputed fact that the party leadership under Bauer opted for a peaceful road to socialism in the most important historical moments of the First Republic, i.e. July 1927, March 1933, and February 1934. In these situations, differences of opinion between party wings were irrelevant. 
able functions of democracy in the proletarian struggle for a new social order prompts a query: how did he reconcile his parliamentary hopes with the inevitability of socialism? In fact, the answer is far simpler than the question itself. The inevitability of socialism due to objective historical laws was a dogma of the Second International. With the passage of time, it degenerated into rhetoric, though admittedly some Social Democrats, including Bauer, unflinchingly believed in it until the end. Even so, faith did not prevent them from focusing on specific duties in their political practice, including using parliament as a platform. The Social Democrats regarded reforms that helped to improve the condition of the working class in the bourgeois state as necessary steps to overcome the capitalist system. Consequently, all reforms achieved through parliament were regarded as stepping-stones on the path to socialism - no distinction between short-term and long-term objectives was made. The postwar social-democratic movement preserved this sentiment, believing there was no need to discontinue capitalist property relations or attack bourgeois democracy, but rather to take advantage of the legal framework of the state to win economic and political reforms in the interest of the broadest social layers.

As it was Bauer's belief that bourgeois democracy represented a transitional stage between capitalism and socialism, it is necessary to assess the three central premises upon which Bauer based his idea of democracy's inevitable development towards socialism. The first was that the democratic forms of the capitalist state were relatively enduring. The second was based on a sociological argument: the number of employees grew as members of the middle classes became declassed, and this affected their political consciousness. To advance their own interests, Bauer thought, they would endorse the programme of Social Democracy, which would lead the workers' party to victory. Up until 1932, Bauer offered no explanation as to why the economic crisis saw the working masses bolster the ranks of the fascists rather than the Social Democrats.

The third premise decisively shaped the idea that bourgeois democracy was a prerequisite for socialist transformation. It contained an important idea of Bauer's unique position in the socialist movement. He assumed that it was possible to deepen democracy by associating the principle of popular sovereignty with the social and economic realms. In his texts, he developed the concept of functional democracy to substantiate this. The core idea of functional democracy was that the democratic social structures that made up a political system evolved from below.

The concept of functional democracy was an integral component of Bauer's dynamic model of democracy - one might say a supplement to political democracy. His understanding of functional democracy and its special variation, industrial democracy, requires some explanation. In layman's terms, functional 
democracy comprised two types of micro-democracy: democracy at the level of groups or organisations, and democracy in the workplace. In relation to democracy as state order and political principle, these two types of democracy played a subordinate role, and it is not possible to define them conclusively because Bauer's statements were imprecise. Even so, it is feasible to attempt to describe them by looking at the constitutive traits of functional democracy and the tasks they were designed to serve.

Bauer employed the term 'industrial democracy' when discussing the socialisation programme for the society of the future and outlining its economic structure. His models were largely based on writings by Sidney and Beatrice Webb and the guild socialists, particularly George Douglas Howard Cole. ${ }^{28}$ For Bauer, the term had not only an economic but also a political dimension. He understood it primarily as workers' direct involvement in the administration of production through self-management in the factories, and ancillary participation through democratically organised trade unions, industrial councils, professional associations for public servants, workers' and peasants' co-operatives, and consumer associations. Moreover, the term was associated with producer self-management in the industries. ${ }^{29}$ As to the structure of industrial democracy, Bauer implied a transition from democratic internal regulations in the

28 The term 'industrial democracy' was popularised at the turn of the nineteenth and twentieth centuries by Sidney and Beatrice Webb - see Webb 1897. The creators of guild socialism, GDH Cole, Samuel George Hobson, Alfred Richard Orage and Arthur Penty, adopted it. They elicited the ideas of Marxism, syndicalism and Fabianism. The emergence of guild socialism refers to the architect Arthur Penty's book, The Restoration of the Guild System (1906) - popularised in New Age magazine from 1908 onwards. The core principles of this were the organisation of the domestic system of co-operative production, changing the form of remuneration, and transforming the trade unions into organs of production selfmanagement. The trend gained influence due to Cole's 1913 book, The World of Labour, which aimed to put the medieval idea of guilds at the service of the modern workers' movement. Cole presented a model that would exclude the capitalists from the production process and reconcile the interests of the immediate producers and consumers. It was to be based on a decentralised form of economic organisation: guilds - i.e. trade unions converted into production associations - were to regulate the economy autonomously. Meanwhile, a central political organisation would own the means of production as a unitary state power and represent the interests of consumers. At consumer request, it would also control the economic policies of the guilds. The principles of internal democratisation, social control, and self-management were intrinsic to this model.

29 Bauer did not conceal the fact that full industrial democracy could only be achieved if the working class assumed state power or at least significantly participated in government. He was also aware that the workers were neither prepared nor mature enough to manage production. This was the reason why he stressed the extra-economic significance of the 
factories towards an integrated system where groups of workers would be represented by profession. These forms of representation would serve as organs of social control and organisation to protect workers' interests. In Western democracies after World War II, these suggestions were essentially revived as demands to create strong union centres and establish co-management in workplaces.

It appears far more difficult to assess what Bauer meant by 'functional democracy'. ${ }^{30}$ It is comprised of two aspects. Firstly, it required democracy on a basic level, i.e. as broad as possible popular participation in local administration and self-administration bodies to influence communal, environmental, cultural and educational policies. Secondly, the working class and its pressure groups as a mass would need to compel the government to make decisions beneficial to all social layers. In other words, the executive would be subjected to the control of parliament and social organisations. If strong extra-parliamentary interest groups, mainly workers' associations, were established, then the government would not only require support in parliament for the duration of its legislative period, but additionally seek the approval of autonomous citizens' organisations to legitimise its actions. He did not go into more detail about the principles and criteria for such citizens' organisations. Their purposes, however, were clear: decentralise state power by assigning part of the legislative and executive responsibilities to power holders at local and self-administration levels; increase social control; preserve the interests of the working masses and ensure that their goals are met. Bauer believed that functional democracy would allow citizens to influence government and administrative decisions as a form of extra-parliamentary authority, as well as transform bourgeois rule into working-class rule within the framework of parliamentary democracy. Most of all, it would encourage citizens' initiative, change their attitude towards the state, and develop their awareness of shared responsibility and social commitment. Core elements of Bauer's concept of functional democracy have become fundamental components of contemporary socio-political practice in the West.

socialisation programme so rigorously. For him, industrial democracy was a means to prepare workers for the administration of the state and production in the future, as well as raise their political and class consciousness. With regard to the question of industrial democracy, Bauer went so far as to deny the necessity of carrying consciousness into the working class 'from outside'. This can be explained by his belief that the working class could develop political consciousness of its own accord if it were in possession of a tool such as industrial democracy.

30 Drawing on Bauer, Ernst Fraenkel introduced this category in the discussion about the political order in the Weimar Republic. See Butterwege 1981. 
The demand to expand democracy is one of Bauer's most valuable ideas and deserves to be popularised in countries that aim to reinforce their democratic structures. The principle at the heart of Bauer's plea was that he wished to continue prioritising political democracy as a prerequisite for the existence of extra-parliamentary forms of democracy.

\section{Democratic Socialism}

Bauer developed his concept of democratic socialism during the second half of the 1930s. It was based on a sociological analysis of the ways in which parliamentary forms of rule functioned in the bourgeois state under given sociopolitical conditions. Considering the experience of the counter-revolutionary period, Bauer saw himself forced to admit that in practice, democracy did not necessarily respect popular sovereignty. The bourgeoisie had means of material and immaterial violence at its disposal. Moreover, it succeeded in using pettybourgeois and peasant parties, which had the support of broad masses, as tools to enforce its overriding political and economic objectives. Towards the end of the 1920s, Bauer surrendered his duty to democratise the bourgeois political order. Instead, he began to express his belief in the class character of bourgeois democracy, a conviction that had been present in his texts since before World War I, in definitive terms. He now acknowledged that formal safeguards of freedom did not offer protection from economic and political ruling-class pressure: if its class rule was under threat, the bourgeoisie was quite prepared to renounce democratic principle and resort to dictatorship. When the autumn of 1930 came, the dissolution of the bourgeois bloc, which effectively meant the demise of the bourgeois republic, confirmed Bauer's predictions. The Social Democrats' delusions that it was possible to engage with the bourgeois camp at a parliamentary level had been destroyed. ${ }^{31}$

Bauer became increasingly sceptical about bourgeois democracy as the fascisisation of Austria advanced. The experience of fascist counter-revolution convinced him that the capitalists had to be fundamentally deprived of economic power if true democracy was to be achieved. However, Bauer's ideological evolution was not particularly profound. His criticisms of bourgeois democracy by no means implied that he endorsed the dictatorship of the proletariat as an alternative. One contention which had arisen from his philosophical perspective that defined a specific axiological option was the fundamental 
difference between democracy and dictatorship. This difference was the degree to which basic freedoms were realised under these two forms of government. Dictatorship, for him, meant the abolition of the principle of freedom, the basis of the socialist idea. A state of dictatorship where all the power to make decisions was, by definition, in the hands of a small group, excluded the initiative of the proletariat, without which socialism was impossible. Like Kautsky, who had coined the term, Bauer advocated democratic socialism - a form of social organisation based on the socialisation of production and a democratic political order. According to Bauer, socialism was inseparable from democracy. Its core value was the freedom of the individual, by which he referred to a freedom that individuals are able to use consciously.

The antagonism between democracy and dictatorship asserted by Bauer must also be assessed. As many of his statements attest, he shared Max Adler's belief that the two concepts were not contradictory in Marx and Engels's doctrine and had only become opposites with the practice of Bolshevism. Privately, however, it appears that Bauer was not entirely sure if this was accurate. In fact, Bauer's idea of dictatorship and Marx's were clearly divergent. Firstly, Bauer used the term 'dictatorship of the proletariat' to describe a form of government based on the rule of a minority. Consequently, he saw no possibility to reconcile this state form with the democratic organisation of social and political life. Moreover, he was well aware of the true meaning behind Marx's formulation: Marx used it to describe a stage in the construction of a classless society, a declaration of intent to change property relations and abolish classes. Without doubt, the use of force was part of this project. It would be naive to expect that such radical social changes might be achieved by peaceful democratic means, and one can hardly suspect Marx of such naivety. Thirdly, Bauer noticed the ambiguity with which Marx employed the term 'dictatorship' when referring to the new type of state. To the extent that socialism would allow the working class to exercise power by democratic means, Bauer argued, the term 'dictatorship' would become superfluous. A dictatorship subjected to democratic control, after all, would lose its dictatorial character. This interpretation of dictatorship, according to Bauer, was practically identical to the concept of popular rule. In light of Bauer's insights, it is important to draw a line of distinction between a working-class government and a dictatorship of the class. There is no such thing as a dictatorship of the working masses, as it inevitably degenerates into a dictatorship of their elected representatives. There is no way to prevent the democratically elected leadership from transforming itself into the dictatorship of a group or individual. In short, it is impossible to make a dictatorship subject to social control as the mechanism of dictatorial rule precludes such an option. 
In the 1930s, under the impression of historical events such as the defeat of the Austrian workers' insurrection, the demise of the party, and the establishment of an authoritarian state, Bauer modified his view of the dictatorship of the proletariat. Even so, he consistently opposed the implementation of a proletarian dictatorship, merely accepting it as a provisional measure in the working-class struggle for state power. Bauer wrote:

The dictatorship of the proletariat is not and must not be an end in itself. It is only a means that the working class must use on its historical road to abolish class divisions in society and thus create the conditions for a socialist democracy. The dictatorship of the proletariat can therefore only be the constitution of a transitional stage in the development towards socialist democracy. 32

our translation

Bauer's notion of a 'democratic dictatorship' was not indistinguishable from Lenin's theory of dictatorship. Violence is permitted as a means to initiate the transformation of the political order, yet such measures are only tactical. Once the task of depriving the capitalists of power has been achieved, the dictatorship must be immediately abolished and replaced by the foundations of full democracy. Bauer opposed the dictatorship of the proletariat as a system of government until the end of his life. What is more, the only political order that he wished to defend was bourgeois democracy. As late as 1936, he stressed:

For as long as the balance of class power in Europe does not confront the peoples with a choice between bourgeois democracy and proletarian dictatorship, the proletariat in its historical practice must defend bourgeois democracy against fascism in the democratic countries and attempt to win back the most basic democratic freedoms in the fascist countries. Until then, the struggle for democracy in these countries - that is to say, bourgeois democracy - is the real, daily practice of the workers' move-

'Die Diktatur des Proletariats ist nicht Selbstzweck und kann nicht Selbstzweck sein. Sie ist nur das Mittel, dessen sich die Arbeiterklasse auf ihrem geschichtlichen Wege bedienen muss, um die Klassenscheidung der Gesellschaft zu beseitigen und damit die Voraussetzungen einer sozialistischen Demokratie zu schaffen. Die Diktatur des Proletariats kann also nur die Verfassung einer Übergangsepoche zur sozialistischen Demokratie sein' Bauer 1980w, pp. 391-2. 
ment. The dictatorship of the proletariat, in contrast, is merely a vision of the future based on socialist theory. ${ }^{33}$

our translation

Bauer's tireless opposition to the dictatorship of the proletariat begs the question as to what 'state of the future' he envisioned. In this respect, it is worth pointing out that Bauer was one of the few Marxists to formulate the programmatic principles of a new political and economic order. Although these were essentially no more than basic outlines of a social organisational model, this did not diminish the value of Bauer's effort. Rather than educing the classicalMarxist texts, which offered but the faintest, utopian outlines, he based his outline on his own theories of democracy and the state. When reconstructing Bauer's vision of a 'state of the future', the basic assumption at its core should be the starting point of analysis: Bauer saw the necessity for democracy to evolve internally from bourgeois via proletarian and onwards to socialist democracy. The logical conclusion from the 'three phases model' is that the capitalist state evolves into a workers' state during the first phase and only becomes socialist during the second. This evolutionary model of transformation already contains the rudiments of the polemics Bauer would later wage against Lenin's interpretation of Marxism. For Lenin, who tended to avoid the term 'socialism', communism was a socio-economic formation that would follow immediately after capitalism in the form of a classless and stateless society based on horizontal self-management. Bauer, on the other hand, strictly rejected such an interpretation. His vision was firmly rooted in a perceived necessity to preserve the political dimension of the state. Unlike Lenin, Bauer did not believe that the seizure of power by the proletariat would immediately lead to the abolition of the class state. If the workers acquired control over the leadership of the state, he argued, this would effect a change in its class structure, but not its abolition. To be precise, a proletarian state built on democratic foundations would emerge during the first phase - one that has nothing to

33 '[S]olange die Machtverhältnisse der Klassen in Europa die Völker nicht vor die Wahl zwischen bürgerlicher Demokratie und proletarischer Diktatur stellen, sondern vor die Wahl zwischen der bürgerlichen Demokratie und dem Faschismus, solange muss das Proletariat in seiner geschichtlichen Praxis in den demokratischen Ländern die bürgerliche Demokratie gegen den Faschismus verteidigen, in den faschistischen Ländern die elementarsten demokratischen Freiheiten wiederzuerobern suchen. So lange bleibt also in diesen Ländern der Kampf um die Demokratie, die bürgerliche Demokratie, die reale, tägliche Praxis der Arbeiterbewegung, die Diktatur des Proletariats nur eine Zukunftsvorstellung der sozialistischen Theorie' - Bauer 1976p, p. 213. 
do with Lenin's 'dictatorship of the proletariat', which represented the superior might of the victorious working class. Its political form would be proletarian democracy, i.e. the rule of the working class emerging from general elections which accounted for the will of the majority and guaranteed civil rights such as freedom of speech, science, faith, assembly and association. ${ }^{34}$ However, Bauer did not regard this phase of development as fully-fledged democracy, which he believed would only come to fruition under socialism and its respective political order, namely socialist democracy. This type of democracy demands further explanation, after all, the term 'socialist democracy' was liberally used in the Eastern Bloc states and might therefore be confused with Communist practice. For Bauer, socialist democracy was politically synonymous with representative democracy. Economically, it was synonymous with a classless community of producers based at the local level (factories, communes, towns) on the principle of self-management. At the time, Bauer intended his concept as a counterweight to the Bolsheviks' theory. It contradicted a majority of their theses, particularly Lenin's argument in State and Revolution, according to which democracy would wither away in a classless society. His argument was also obliquely directed against Lenin's assertion that the Communist Party had a leading role during the process of social and economic transformation. While Bauer remained quiet on the question of political representation in the socialist state, his understanding of 'socialist democracy' precluded the authority of any single political organisation. Indeed, the very fact that Bauer forwent any detailed description of the forms that a socialist political system might take was a hallmark of his excellence. He thus avoided making the kind of prophecies for which the Bolsheviks were known.

It is worth citing another issue associated with the theory of socialism outlined above. In his economic theory, Bauer echoed Marx's insistence that a planned economy should be maintained under socialism. This was by no means at odds with Bauer's call for decentralised self-management in the economic realm. Bauer never conflated the planned economy with authoritarian state regulation in production. Rather, he spoke of a political order based on democratic planning, which would be preceded by debate and thus receive society's consent. This model envisioned the role of the state as being limited to coordinating the actions of economic subjects and ensuring equal opportunities in the course of economic development. Bauer's concept bore no similarity to the Leninist-Bolshevik notion of planning, which required the centralisation of economic decisions. The two solutions were, in fact, opposites: the relation- 
ship between them was roughly analogous to the relationship between the integral concept of socialist democracy and the Bolsheviks' theoretical outlines for a future political order.

\section{Coalition Work}

Among Marxist theorists, only Lenin entertained the illusion that capitalism could be abolished and communism built in its ruins during his lifetime. ${ }^{35}$ His contemporaries, the Social Democrats in Western Europe, were far more cautious about the historical moment at which the transformation of the political order was to unfold. Accordingly, the vision of a future state order merely had theoretical and propagandistic value in Bauer's doctrine, whereas for the political practice of Social Democracy, it was irrelevant. The distant strategic goal was obscured by day-to-day politics, whose objective, according to Austromarxist revolutionary and state theory, was to gain a strong position for the working class in the capitalist state. This would serve the class as a foundation for a future seizure of power. Parliament was designated as the place where the fate of the proletariat would be decided.

As this is precisely what the party regarded as its core strategy since the Hainfeld party congress, it accepted the limitations that this choice demanded in the struggle for socialism. In the parliamentary arena, the party had a choice between two tactics: it could either continue the struggle for its programme in isolation, aware that its chances of success depended upon the number of voters it could win. Alternatively, it could negotiate with other groups in parliament and seek to come to an understanding on less controversial questions. From its inception up until 1914, the SDAP did not collaborate with bourgeois parties at all. There were several reasons for this. For one, the existing parties lacked common purposes: suffice it to say, the Christian Socials and Greater Germans were not interested in SDAP-led campaigns for universal suffrage and the creation of strong trade unions to protect the interests of workers against despotic bosses. Positions on the national question also differed. Some features of the Austrian empire's party system need to be considered. Firstly, each party had its own electorate, and each electorate had distinct expectations of their politics. Secondly, the Social Democrats, although increasingly a mass party commanding an ever-greater number of seats in parliament, were no match

35 However, he grew increasingly sceptical about the possibility of building communism quickly in the Soviet Union in the 1920s. 
for the united forces of the bourgeois-peasant camp. In addition, any potential collaboration between different political groups was thwarted by the Marxist dogmatism that prevailed in the SDAP: any co-operation with the class enemy was rejected on ideological grounds. The 1917 resolution of the left and the 1918 national programme of the left are informed by very similar sentiments.

After the demise of the monarchy, the SDAP leadership reconsidered its stance on collaboration with other parties. In October 1918, the Austrian Social Democrats were inclined, much like their German sister party, towards coalition policies, even if the decision of the party leadership was not supported by rank and file members. ${ }^{36}$ The theoretical assumptions and socio-political conditions that convinced SDAP leaders to adapt their attitude to coalitions are worthy of investigation. In the theoretical domain, the desire to uphold the concept of peaceful revolution was crucial, which corresponded with the party's fear of a violent attempt by the indignant masses to usher in a proletarian state. Joining the coalition was understood as a necessary step towards defending the early democratic gains of the republic, a guarantee for the continuation of the reformist road, and a safeguard against Bolshevisation. ${ }^{37}$ The Social Democrats' belief that the transformation of the political order had been premature led to a novel situation. For the first time in the history of Austrian parliamentarism, inter-party quarrels were secondary to the concern for a common objective. To summarise, the theory of a historical necessity to engage in coalition work, unanimously supported by the leadership at the dawn of the republic, was entrenched in their desire to protect bourgeois democracy. Bauer and Renner's theories of democracy and the state provided justifications for this.

Nonetheless, it is hard to entirely deny Bauer's 1919 assertion that the decision to engage in a coalition was forced upon the party by the socio-political balance of forces. ${ }^{38}$ True enough, no party actively desired a coalition, nor

36 No one spoke resolutely against a coalition at the 1918 congress. When the coalition government was formed with the participation of the SDAP on 30 October 1918, this caused outrage among workers, as they were hostile towards collaboration with bourgeois parties. Renner stressed this a few days later at a state council meeting. See Pfabigan 1982, p. 146.

37 At the first meeting of the provisional national assembly, Victor Adler claimed that Social Democracy would not abandon its political goals when entering the coalition - see Berchtold 1967, p. 32. This proclamation did not change the reality that both the Social Democrats and Christian Socials regarded the coalition as the only way to prevent the emergence of a proletarian dictatorship. Compare Leopold Kunschak's speech of 30 May 1919, cited by Leser 1986, p. 280; and Bauer 1920b, p. 255.

38 At the October 1919 party congress, Bauer explained that 'the coalition is a bitter necessity 
did any of them wish for the division of state power to remain a permanent condition. Not so much the intention or ideological orientation of the party, but the real social and political circumstance was decisive. The bourgeois parties could have formed their own government, but they capitulated in the face of revolutionary threat. Similarly, it would have been impossible for the Social Democrats to form a government on their own, given the anti-socialist resistance in the regions. The necessity of coalition, then, was the result of cool calculation: just as the Christian Socials could not have governed Vienna on their own, so the Social Democrats could not have ruled all of Austria without Christian Social support.

As far as the socialists were concerned, the coalition government embodied the first stage of revolution, although this conviction had more to do with the expectations they attached to the coalition than the actual results. Its objectives were to consolidate the state and implement reforms in the interest of broad social layers. In practice, the coalition was active in three areas: constitutional, socio-economic, and foreign affairs. Aside from legislative issues, its policies had little to do with socialist aims. Especially from the second half of 1919 onward, when the bourgeois bloc no longer felt threatened by the domestic situation and brazenly began to consolidate its power, Bauer's prophetic words of 1907 had come true as far as the working masses were concerned. Back then, he had argued:

If the Social Democratic movement ... one moment [joins] forces with this and the next moment with that political group, perhaps even forming a part of the governmental majority and participating in government itself ... it appears itself to be an institution of the capitalist state; it shares responsibility ... for all the misery and exploitation endured by the working people in capitalist society. ${ }^{39}$

During the autumn of 1919, the SARA faction defended the workers who were dissatisfied with the political direction in which the SDAP leadership was heading. It demanded more radical measures, more power to the left wing of the SDAP, and that the party leave the coalition. On 14 September 1920, Joseph Frey commented during the meeting of the Vienna SDAP executive:

for us all, yet for the moment, it is a necessity nonetheless' - quoted in Reimann 1968, p. 335 .

39 Bauer 1996, pp. $445^{-6 .}$ 
The only means to achieve this is the unification of the Social-Democratic and Communist parties. However, the coalition stands in the way of unification. I prefer a coalition even with the worst, dirtiest Communist to a coalition with the Christian Socials and Greater Germans. ${ }^{40}$

our translation

A majority of the working class endorsed the demand to withdraw from the coalition, which the left at the party congress of 1920 repeated. The workers urged the leadership - Bauer in particular - to take a firm stand.

In 1918, Bauer did not particularly desire a coalition with bourgeois parties and had reservations about its stability. ${ }^{41}$ In spite of this, neither he nor his closest associates managed to present a clear position on co-operation with other political groups during the entire period of the First Republic. It is difficult to blame them. Their perspectives evolved on the balance of class forces, and the arguments they offered the working class intended to validate party policies. Bauer's stance at the 1920 SDAP congress illustrates this. He admitted that permanent co-operation with bourgeois parties inevitably involved a change of the party line. As an aside, there was a far more significant problem behind his statement, which, even if the socialists did not fully realise it at the time, became paramount after World War II. The 1920 discussion was not so much about revising the current party line as it was about changing the very character of the party. As it were, the question was whether the SDAP should remain a class party, or whether the experience of coalition work militated for it to become a party of the entire populace. Incidentally, the postwar social democrats of Western Europe unequivocally solved this question when renouncing the myth of the class character of their parties, which they considered of little use given the changed social and political circumstances. Bauer protested that the party must withdraw from the coalition at the 1920 party congress. To rationalise this, he drew on the Marxist notion that class contradictions in capitalist society would steadily increase. He argued that 'the governing of the bourgeois state, for as long as it remains a bourgeois state naturally falls to the bourgeois class. The stance of the proletariat towards the bourgeois state even in its republican form is one of opposition. ${ }^{42}$ In reality, Bauer realised that

'Das einzige Mittel hierzu ist die Vereinigung der Sozialdemokratischen Partei mit der Kommunistischen. Das Hindernis dieser Einigung ist aber die Koalition. Mir ist die Koalition mit dem letzten, dreckigsten Kommunisten lieber als mit den Christlichsozialen und Deutschnationalen' - quoted in Raming 1979, p. 16. 
the SDAP was losing its hegemony and feared rising Communist influence and a potential split in the party. While none of this was unjustified, the Social Democrats' political practice and their logic for rejecting any further collaboration with bourgeois parties were not the same as the reasons they offered to the masses. In addition, the bourgeois parties did not desire further SDAP participation in government any more than the Social Democrats did. A Christian Social and Greater German bloc could very well do without the Social Democrats. The latter, meanwhile, were aware of their powerlessness and were thus forced to abandon the idea. When the elections on 17 October 1920, the first after Renner's resignation, resulted in an unexpected ascendancy of the bourgeois parties, the Social Democrats joined the opposition using a dispute on military legislation as a pretext. ${ }^{43}$ The exit from the coalition did not shake the party leadership's faith in the democratic road to socialism, despite the fact that engaging with the coalition was one of the pivotal aspects of this strategy. The SDAP leaders dismissed the affair as a temporary exclusion from power. In 1920, they firmly believed that new fertile ground for resuming coalition work would soon be created. Without a doubt, this was partly due to the deterministic view of history prevailing among Social Democrats. ${ }^{44}$ On a more trivial level, the Social Democrats' hope to re-enter a coalition was also due to their expectation that the victorious parties' policies in government would soon end in disaster.

Yet their hopes were never actualised. The bourgeois bloc consolidated its power in the state. What is more, in 1922, after having declined Bauer's offer to participate in government, it managed to navigate the country out of the economic crisis without the Social Democrats' co-operation. Meanwhile, the Social-Democratic party, which on Bauer's advice had remained in opposition, was debilitated to such a degree that it was completely at the mercy of the bourgeois parties' paramilitary formations when the wave of terror escalated after $1927 \cdot{ }^{45}$ After 1920 , there was only one real opportunity for the Social

43 The Social Democrats demanded replacing the standing army with a popular militia. This suggestion provoked vehement resistance from their coalition partners - see Leser 1986, p. 281. The election results played a far greater role in the SDAP's decision: in 1919, the Christian Social Party increased its number of mandates by 19 and the Greater German People's Party by two, while the SDAP lost seven seats in parliament. This change in balance reflected the gradual dissipation of the revolutionary wave and consolidation of bourgeois dominance.

44 Compare Leser 1979, p. 33.

45 Bauer wrote about the suggestion he had made to Seipel on the front page of the ArbeiterZeitung of 24 August. 
Democrats to participate in government, namely when Ignaz Seipel offered to form a coalition. They declined.

With regard to their rejection of the offer, it is important to remember that the position of the SDAP leadership in 1931 resulted from a 1927-30 discussion about Social-Democratic participation in coalitions. The discussion came to the fore at the 1927 party congress, where two contending positions emerged. Bauer's group was against coalition work, while Renner's faction supported it. At the time, Bauer discussed three different situations under which coalitions were formed: working-class dominance, balance of class power, and bourgeois dominance. He categorically rejected coalitions in the last case. The weakness of the workers' party, he argued, would lead to inefficient action on the part of Social-Democratic ministers, and the masses would ultimately lose confidence in their leaders. ${ }^{46}$ Moreover, he claimed that coalition work was only beneficial for the working class in a situation when it was in the ascendancy. ${ }^{47}$ Subsequently protesting against a coalition at the congress, he offered the dubious argument that there was little point in sharing power with bourgeois parties since electoral support for Social Democracy was on the rise. This, according to him, gave the socialists hope for their own government in the near future. Bauer's optimism was completely unfounded. Renner, Oskar Helmer and Heinrich Schneidmadl accused the party leader of spreading illusions as to the power and significance of the party. Contrary to Bauer's convictions, the party was so weak from 1927-30 onward that the bourgeois bloc ceased to consider Social Democracy a political factor in the Austrian state. After 1931, Bauer made an effort to obscure this state of affairs from the working class. He vindicated the exclusion of Social Democracy from the political arena by claiming that coalition work only served to buttress the foundations of the capitalist state. $^{48}$

46 See Bauer 1928, p. 335 and Bauer 1930, p. 193.

47 Ibid.

48 In 1930, Bauer wrote: 'under favourable conditions, the participation of Social Democrats in government can be beneficial, even necessary. It can protect the working class against threats and be to its advantage. It can significantly strengthen the resistance of the democratic state against the pressures of the capitalist plutocracy. However, leaving aside revolutionary periods such as 1918-20, it cannot abolish the bourgeois character of the state' (our translation). Original: 'Die Teilnahme der Sozialdemokratie an der Regierung kann unter günstigen Voraussetzungen nützlich, notwendig sein. Sie kann die Arbeiterklasse vor Gefahren bewahren und kann der Arbeiterklasse manchen Vorteil bringen. Sie kann die Widerstandskraft der demokratischen Staatsgewalt gegen den Druck der kapitalistischen Plutokratie wesentlich stärken. Aber sie kann - von revolutionären Zeiten, wie 
Similarly, Seipel's offer did not mean that he recognised the Social Democrats as equal partners. Nor did it imply that the Christian Socials were revising their political line, even if certain factions of that party were prepared to co-operate with the Social Democrats at the end of the 1920s. According to Staudinger, the leadership of the Christian Socials' parliamentary club did not intend to grant the SDAP proportional representation in a future coalition government. ${ }^{49}$ Seipel's motivations for the offer of a coalition were prompted by the Christian Socials' anxiety that the state could progress in an increasingly authoritarian direction. In light of electoral losses and economic crisis, they were worried that they might not be able to salvage democracy on their own. The Social Democrats offered two reasons for declining the offer. Firstly, the position granted to the Social-Democratic party in a coalition government would have been far too weak. Secondly, participation in such a government went against the wishes of the party majority. ${ }^{50}$ Bauer's crowning argument was his claim that the sheer act of Social Democrats entering government when capitalism is subject to the heaviest turmoil ... would put us at the great risk of merely co-administering the affairs of collapsing capitalism as part of this government, while not being able to adequately serve the interests of the working class and ideals of socialism' (our translation). ${ }^{51}$ The Social Democrats wanted

1918 bis 1920 abgesehen - den bourgeoisen Charakter des Staatswesens nicht aufheben' Bauer 1930b, p. 310.

See Staudinger 1984, p. 12.

5o Julius Deutsch was the only member of the party leadership to speak in favour of entering a coalition. Renner, who had been waiting for such an opportunity for years, agreed with Bauer. Modern historians disagree over whether the Social Democrats should have joined the government in 1931 - see Staudinger 1984, p. 6; Simon 1984, p. 12; Maimann and Mattl 1984, pp. 6-7. As Haas states, a partial collaboration between Social Democrats and Christian Socials existed from 1932-3 in some provinces, e.g. Lower Austria, despite the SDAP's rejection of the coalition offer. After 15 March 1933, the SDAP leaders were prone to a politics of compromise. They offered Dollfuss a co-operation against the Nazis, for instance, which the chancellor declined. See Haas 1990, p. 422 and p. 424.

'... [D]er bloße Eintritt von Sozialdemokraten in die Regierung in dieser Zeit der schwersten Erschütterung des Kapitalismus ... würde uns in die große Gefahr bringen, dass wir in dieser Regierung nur die Geschäfte des zusammenbrechenden Kapitalismus mitadministrieren sollten und nicht in der Lage wären, wirklich den Interessen der Arbeiterklasse und den Idealen des Sozialismus in ihr entsprechend zu dienen' - SDAP 1931, in Documents, Programmes, Protocols, p. 29. It seems justified to assume that the Social Democrats' participation in government would have involved a joint effort to save the bankrupt banks and therefore inevitably would have led to cutting unemployment allowances. As Renner mentioned in light of Bauer's strong resistance, joining the coalition would have only been 
to evade the responsibility for the deteriorating economic situation in Austria and the economic crisis. In 1931, their calculations did not consider that the introduction of socialism was probably not a realistic alternative for Austria at the time. In all likelihood, the choice was one between defending bourgeois democracy and facing a fascist dictatorship.

Many Austrian scholars agree that Bauer was adverse to a collaboration with bourgeois-peasant parties. ${ }^{52}$ While this is essentially justified, a few complementary remarks are necessary. Bauer's attitude towards coalitions was influenced by his struggle to preserve the unity of the workers' movement and protect its immediate interests. Considering deteriorating economic conditions for the working class, such as rising unemployment and a relapse into inflation, this was no easy task. What is more, it bore the real danger, which would partly come true, that the workers might leave the ranks of the Social Democrats and join the Communists and fascists instead. Bauer was neither an advocate nor an adversary of coalitions. ${ }^{53}$ For him, judging the expediency of forming a coalition depended on the balance of political and class forces across the country. Depending on the occasion, he was in favour of coalition to balance opposing class forces, which logically resulted from his theory of a 'balance of class power'.54 Given the domestic situation in Austria in 1931, to decline a coalition offer was not a thoroughly considered decision. Following Susanne Miller in her essay, 'Politische Führung und Spontanität in der österreichischen Sozialdemokratie' ('Political Leadership and Spontaneity in Austrian Social Democracy', 1985), one may wonder whether collaboration between the SDAP and Christian Socials would have been a viable option. It is equally debatable as to whether it could have averted the danger of fascism at home. ${ }^{55}$

The historical fate of the coalition in the First Republic laid bare the contradictions of the 'third way' under bourgeois-democratic conditions. The political structures only allowed the Social Democrats marginal room for man-

possible at the cost of splitting the party - a price no Social Democrat wanted to pay. See Renner 1952b, p. 41.

$5^{2} \quad$ See Kulemann 1979, p. 238; Reimann 1968, p. 336; Leser 1986, p. 281; Hanisch 2011, p. 167.

53 Many scholars share this assessment of Bauer's legacy. Leser, for instance, writes: 'He was not an opponent of coalition governments as a matter of principle' (our translation) Leser 1964, p. 70 .

54 Likewise, Hanisch argues, 'for the phase of relative stability, it is possible to sum up as follows: Bauer did not reject coalitions as a matter of principle, but the conditions were determined exclusively by the interests of the working class, not by the interests of the whole of society' (our translation) - Hanisch 2011, pp. 211-12. 
oeuvre when the bourgeoisie was weak during the post-revolutionary period. It also offered the class enemies of Social Democracy a legal framework for their rebirth and instigations of extra-parliamentary means of violence. These groups managed to eliminate the workers' party from political prominence without great difficulty. In opposition, the party was unable to resist the forces that annihilated democracy. Nor could it construct the tactical prerequisites for an effective struggle to reclaim its position in the state. The Social Democrats' strategic objective of defending bourgeois democracy remained unfulfilled, wishful thinking. 